\title{
Experimental Determination and Modeling of the Moisture-Sorption Isotherms and Isosteric Heat of Tobacco Leaves
}

\author{
Foullanine Meriama ${ }^{1,2 *}$, Bennaceur Said ${ }^{2}$, Loumani Akil ${ }^{1}$, Mediani Ahmed ${ }^{1}$, Moungar Houcine ${ }^{1}$, Djaber Abdelkrim ${ }^{1}$, \\ Tigani Cherif $^{1}$, Larbi Ahmed Amine ${ }^{1}$, Draoui Belkacem ${ }^{2}$ \\ ${ }^{1}$ Unité de Recherche en Energies Renouvelables en Milieu Saharien, URERMS, Centre de Développement des Energies \\ Renouvelables, CDER, Adrar 01000, Alegria \\ ${ }^{2}$ Équipe Confort Thermique des Bâtiments et des Serres, Laboratoire d'Energétique en Zones Arides, Université THRI \\ Mohamed de Béchar, Béchar 08000, Algeria
}

Corresponding Author Email: M.Foullanine@urerms.dz

https://doi.org/10.18280/i2m.200504

Received: 13 September 2021

Accepted: 19 October 2021

\section{Keywords:}

sorption isotherm, solar drying, gravimetric method, isosteric heats, nicotiana tabacum $L$., GAB and PELEG models

\begin{abstract}
During a forced convection sun drying and storage operation, the equilibrium water content of a product to be dried is critical. These figures are frequently derived using isothermal sorption curves. The calculation of isotherms is a necessary step in determining the distribution and intensity of water connections in products. for that this paper concentrates on the experimental determination of the adsorption-desorption isotherms for various temperatures $\left(40,50\right.$, and $\left.60^{\circ} \mathrm{C}\right)$ of the Nicotiana Tabacum $L$ plants. From which we had established the relationship between the water activity and the water content in the product. However, the aforementioned determination was carried out by the static gravimetric method. Eight saturated salt solutions have been utilized in applications such as $\left(\mathrm{KOH}, \mathrm{KCl}, \mathrm{MgCl}_{2}, \mathrm{MgNO}_{3}, \mathrm{~K}_{2} \mathrm{CO}_{3}, \mathrm{BaCl}_{2}, \mathrm{~K}_{2} \mathrm{SO}_{4}\right.$, and $\left.\mathrm{NaCl}\right)$. Hygroscopic equilibrium was completed after 13 days for temperature $40^{\circ} \mathrm{C}, 11$ days for $50^{\circ} \mathrm{C}$, and 9 days for $60^{\circ} \mathrm{C}$. The overall experimental sorption curves are summarized by six models (HENDERSON, modified HALSEY, OSWIN, GAB, modified BET, and PELEG). The sorption isotherms built using the Clausius-Clapeyron equation were used to determine the net isosteric temperatures of desorption and adsorption of Nicotiana Tabacum L. The results for the adsorption-desorption isotherms found are type III according to IUAPC. Following the smoothing of the experimental results by different used models, it was found that the models of GAB and Peleg allow having the lowest mean relative errors and correlation coefficient.
\end{abstract}

\section{INTRODUCTION}

The SOLANACEAE family which yields Nicotiana Tabacum $L$., or tobacco, is a plant cultivated annually in warm regions [1]. It comes from Central America, more precisely from Mexico and Venezuela [2]. where it is the most frequently grown of all plants in the genus Nicotiana, and the leaves are getting larger for processing into tobacco as well as it is interesting commercially [3]. It reaches heights of between $50 \mathrm{~cm}$ and 1.5 meters (or even 2.5 meters for some varieties) [1].

Dried N.T.L. widely used for their rich in nicotine, providing the main source of tobacco, it is used in the cigarettes or cigars manufacture, such as it is an immense global industry. N.T.L. is also widely used in traditional medicine.

In India, is used for various skin conditions and therapy applications, for example, over the world, Plant galls extracts are widely used in rheumatic, piles, and stings treatment.

Various pathologies were effectively treated with traditional remedies containing extracts of vegetable galls in many countries: African and Asian [3].

On the other hand, in Pakistan and Cameroon: N.T.L. are used in Ethno veterinary medicine locally as an insecticide and to rid animals of mites and lice [2, 4].

Solar drying has long been thought to be the most extensively employed solar energy technique for food preservation $[5,6]$. Before utilizing tobacco leaves, it's fun to dry them out. The determination of sorption isotherms is an essential step and a privileged means of knowing the distribution and intensity of water binding in agro-food products, which has piqued the interest of many researchers for a long time [7]. Sorption isotherms are of great importance in the agro-food industry, particularly in solar drying, food storage, and preservation operations.

Sorption isotherms curves determination for specified temperature $\mathrm{T}$, the product water content equilibrium Xeq as function of the water activity value aw or the air relative humidity in the equilibrium HRE of the product at the drying end. The sorption isotherms modeling moreover of medicinal plants or agro-food products interesting several researchers. Knowing that, for the henna leaves [8], the marjoram leaves [9], the pumpkin [10], wormwood and pennyroyal leaves [11], palm heart [12], some varieties of dates [13], and the discussion on the employment of the static gravimetric approach [14-21] continues in this regard.

With this goal, this work explores, seeks to improve the isothermal sorption models and the isosteric heat is suggested. however, most improvements have been investigated to describe the most adequate model for the equilibrium state of tobacco leaves (N.T.L.). 


\section{MATERIALS AND METHODS}

Among the procedures for obtaining isotherms for sorption of water in agro-food products, either dynamic methods are used where the sample is placed in a stream of gas, with temperature and humidity maintained constant, without air agitation, or static procedures where the sample to be adsorbed or desorbed is placed in enclosures containing saturated salt solutions and maintained at constant temperature and relative humidity until thermodynamic equilibrium is reached.

Reference [14] analyses and compares various aspects of These procedures to predicts the Allium sativum isothermal sorption models. Nevertheless, there are still some interesting and relevant problems to be addressed. However, studies on the tobacco leave isothermal sorption are still lacking.

\subsection{Used materials}

The N.T. Leaves used during presented work is cultivated in ADRAR region located in the south of Algeria in Saharan climatic condition, we have selected two N.T.L. samples fresh and dried, such cases are depicted in Figure 1.

The present work was effectuated in the solar draying laboratory at the Thermal and Thermodynamics Conversion Division, within the Research Unit Energies in Renewable Energies in the Sahara Medium. Development Centre of Renewable Energies, Adrar, Algeria.
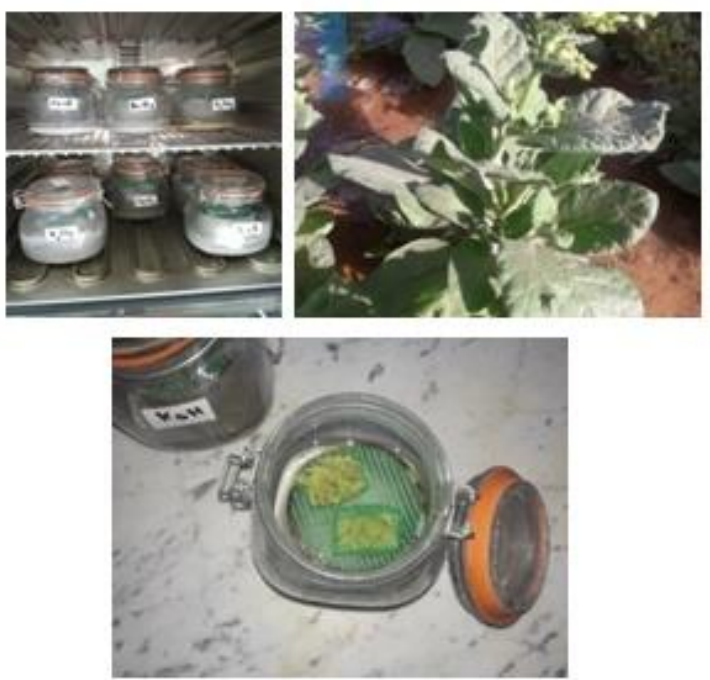

Figure 1. The used procedure, the product presentation and the fresh \& drayed tobacco

Table 1. Water activities of salts used for the preparation of saturated saline solutions [1]

\begin{tabular}{lccc}
\hline \multirow{2}{*}{ Salts } & \multicolumn{3}{c}{ Temperatures } \\
\cline { 2 - 4 } & $\mathrm{a}_{\mathrm{w}}$ à $40{ }^{\circ} \mathrm{C}$ & $\mathrm{a}_{\mathrm{w}}$ à $50^{\circ} \mathrm{C}$ & $\mathrm{a}^{\mathrm{w}} \mathrm{à} 60^{\circ} \mathrm{C}$ \\
\hline $\mathrm{KOH}$ & 0.063 & 0.057 & 0.055 \\
\hline $\mathrm{MgCl}_{2}$ & 0.316 & 0.305 & 0.293 \\
\hline $\mathrm{MgNO}_{3}$ & 0.49 & 0.46 & 0.43 \\
\hline $\mathrm{K}_{2} \mathrm{CO}_{3}$ & 0.423 & 0.456 & 0.45 \\
\hline $\mathrm{NaCl}$ & 0.747 & 0.744 & 0.745 \\
\hline $\mathrm{KCl}$ & 0.823 & 0.812 & 0803 \\
\hline $\mathrm{BaCl}_{2}$ & 0.891 & 0.8823 & 0.8728 \\
\hline $\mathrm{K}_{2} \mathrm{SO}_{4}$ & 0.964 & 0.958 & 0.957 \\
\hline
\end{tabular}

The saturated saline solutions used are: $\mathrm{KOH}, \mathrm{KF}, \mathrm{MgCl}_{2}$, $\mathrm{K}_{2} \mathrm{CO}_{3}, \mathrm{NaCl}, \mathrm{KCl}, \mathrm{BaCl}_{2}, \mathrm{~K}_{2} \mathrm{SO}_{4}$. These solutions make it possible to obtain relative humidity varying from 5.5 to $96.4 \%$ (Table 1).

\subsection{Modeling of sorption isotherms}

In order to interpret the sorption curves obtained, six (6) models described in this work were used for the adjustment and modeling of the adsorption isotherms of tobacco leaves (Oswin, Halsey modified, GAB, Henderson, BET modified and Peleg), (Table 2).

Table 2. Desorption and adsorption mathematical used models $[14,16]$

\begin{tabular}{ccc}
\hline Model & Equations & Parameters \\
\hline $\begin{array}{c}\text { Oswin } \\
\text { Oswin, } \\
\text { 1946) }\end{array}$ & $X_{e q}=A\left[\frac{a_{w}}{1-a_{w}}\right]^{B}$ & $\mathrm{~A}$ \\
$\begin{array}{c}\text { Halsey } \\
\text { modified }\end{array}$ & $X=\left[\frac{-\exp (A+B T)}{\ln a_{w}}\right]^{\frac{1}{C}}$ & $\mathrm{~B}$ \\
\hline $\begin{array}{c}\text { G.A.B } \\
\text { (Anderson, } \\
\text { 1946) }\end{array}$ & $=\frac{\mathrm{B}}{\left(1-B a_{w}\right)\left(1-B a_{w}+A B a_{w}\right)}$ & $\mathrm{C}$ \\
\hline \multirow{2}{*}{ Henderson } & $X=\left[\frac{-\ln \left(1-a_{w}\right)}{A(T+B)}\right]^{\frac{1}{C}}$ & $\mathrm{~B}$ \\
\hline \multirow{2}{*}{ BET } & $(A+B T) C a_{w}$ & $\mathrm{~B}$ \\
modified & $X=\frac{\mathrm{C}}{\left(1-a_{w}\right)\left(1-a_{w}+C a_{w}\right)}$ & $\mathrm{A}$ \\
\hline \multirow{2}{*}{ Peleg } & $\mathrm{B}$ \\
& & $\mathrm{C}$ \\
\hline
\end{tabular}

- Statistical criteria for choosing the appropriate model:

Three factors are cited for the selection of the best equation to describe the adsorption curves $[16,17]$,

- The first criterion is the correlation coefficient (r) was estimated by the Curve Expert 2.6.3 software

- The relative mean error (EMR) given by the relation:

$$
E M R=\frac{100}{N} \sum_{i=1}^{N}\left|\frac{X_{e q_{i, e x p}}-X_{e q_{i, p r e}}}{X_{e q_{i, e x p}}}\right|
$$

- The standard error of the plant water content (EST) expressed by:

$$
E S T=\sqrt{\frac{\sum_{i=1}^{N}\left(\boldsymbol{X}_{e q_{i, e x p}}-X_{e q_{i, p r e}}\right)^{2}}{d_{f}}}
$$

- $\quad$ The correlation coefficient (r)

$$
r=\sqrt{1-\frac{\sum_{i=1}^{n_{\text {exp.data }}}\left(X_{e i}-X_{e_{c a l}}\right)^{2}}{\sum_{i=1}^{n_{\text {exp.data }}}\left(X_{e}-X_{e i}\right)^{2}}}
$$

\subsection{Determination of isosteric heat of sorption}

The isosteric heat of sorption is the energy on fixing the water to the substrate, or else additional heat to the pure water 
vaporization heat that would have to be supplied to dehydrate the product.

The most interesting approach to this issue has been proposed by Lamharrar et al. [11] and Larbi et al. 12], it can be determined from the moisture sorption data using the following equation:

$$
Q_{s t}=-R\left[\frac{\partial\left(\ln a_{w}\right)}{\partial \frac{1}{T}}\right]
$$

Assumed that the isosteric heat of sorption independent of temperature, the integration of this equation gives Eq. (5):

$$
\ln \left(\mathrm{a}_{\mathrm{w}}\right)=-\left(\frac{\mathrm{q}_{\mathrm{st}}}{\mathrm{R}}\right)\left(\frac{1}{\mathrm{~T}_{\mathrm{k}}}\right)+\mathrm{k}
$$

\section{RESULTS AND DISCUSSION}

\subsection{Sorption isotherms}

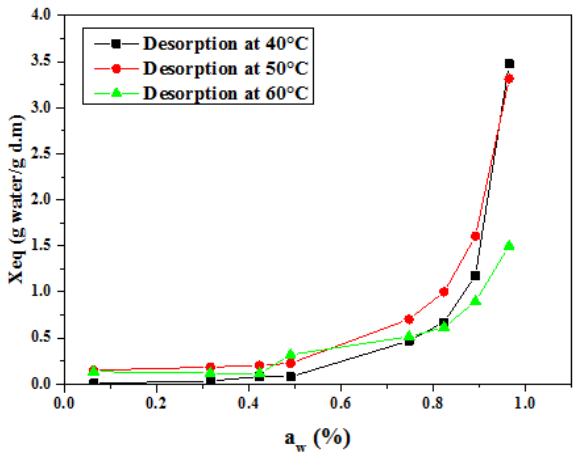

(a)

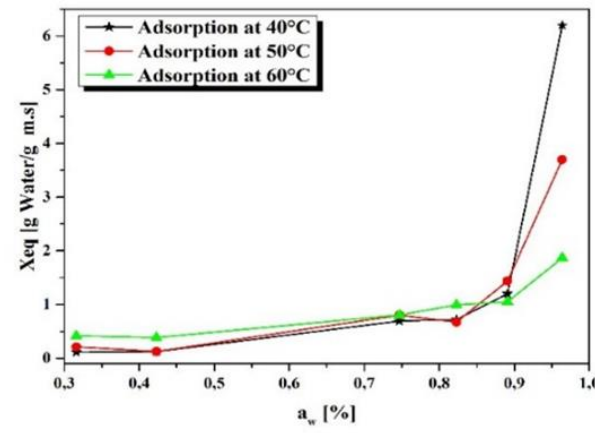

(b)

Figure 2. Temperature influences on the adsorption/desorption isotherms

The hygroscopic equilibrium of the leaves of N. Tabacum is reached after 13 days for desorption and after 11 days for adsorption. The Xeq equilibrium water contents are grouped in Table 3 for three temperatures $40^{\circ} \mathrm{C}, 50^{\circ} \mathrm{C}$ and $60^{\circ} \mathrm{C}$.

Figures 2.a, 2.b, show the absorption and desorption isotherms of tobacco plant at different temperatures 40, 50 and $60^{\circ} \mathrm{C}$, which are evident to take the type III sigmoidal form, according to IUAPC [22].

This is consistent with several agricultural products as well as medicinal and aromatic herbs [17, 19, 23].

Regarding the influence of temperature note that there is a small fluctuation between the temperature values as the water activity increases and the content water equilibrium increases. This is what distinguishes the tobacco plant from most results presented in the literature $[9,24]$, the equilibrium water content increases with the decrease in temperature.
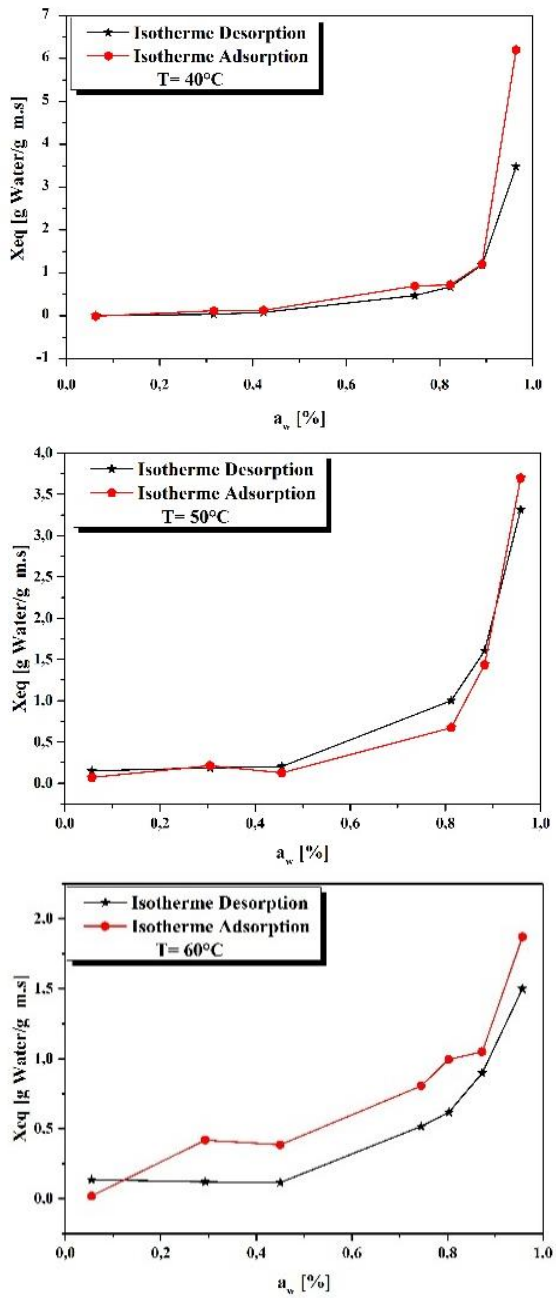

Figure 3. Adsorption \& desorption isotherms comparison at 40,50 and $60^{\circ} \mathrm{C}$

Table 3. The adsorption and desorption equilibrium water content

\begin{tabular}{ccccccccc}
\hline & $\mathbf{4 0}^{\circ} \mathbf{C}$ & \multicolumn{3}{c}{$\mathbf{5 0}^{\circ} \mathbf{C}$} & & $\mathbf{6 0}^{\circ} \mathbf{C}$ & \\
\hline $\mathbf{a}_{\mathbf{w}}$ & $\mathbf{X}_{\mathbf{e q}} \mathbf{a d s}$ & $\mathbf{X}_{\text {eq }} \mathbf{d e s}$ & $\mathbf{a}_{\mathbf{w}}$ & $\mathbf{X}_{\text {eq }} \mathbf{a d s}$ & $\mathbf{X}_{\text {eq }} \mathbf{d e s}$ & $\mathbf{a}_{\mathbf{w}}$ & $\mathbf{X}_{\text {eq ads }}$ & $\mathbf{X}_{\text {eq }} \mathbf{d e s}$ \\
\hline 0.063 & 0.00408 & $/$ & 0.057 & 0.15010 & 0.07103 & 0.055 & 0.13539 & 0.01939 \\
\hline 0.316 & 0.02439 & 0.11491 & 0.305 & 0.18467 & 0.21311 & 0.293 & 0.12017 & 0.41828 \\
\hline 0.423 & 0.04356 & 0.12469 & 0.456 & 0.20311 & 0.12568 & 0.45 & 0.11582 & 0.38504 \\
\hline 0.49 & $/$ & 0.03667 & 0.46 & 0.22615 & 0.37704 & 0.43 & 0.31810 & $/$ \\
\hline 0.747 & 0.43486 & 0.69193 & 0.744 & 0.70325 & 0.80327 & 0.745 & 0.51604 & 0.80609 \\
\hline 0.823 & 0.62674 & 0.72127 & 0.812 & 1.00057 & 0.67213 & 0.803 & 0.61609 & 0.99445 \\
\hline 0.891 & 1.14314 & 1.20048 & 0.8823 & 1.60443 & 1.43715 & 0.8728 & 0.89885 & 1.04986 \\
\hline 0.964 & 5.04432 & 6.19804 & 0.958 & 3.31460 & 3.69945 & 0.957 & 1.49918 & 1.86980 \\
\hline
\end{tabular}


Likewise, in Figure 3, we notice that the absorption and desorption curves are compatible with the general shape of the sorption curves [25], except that for the temperature $50^{\circ} \mathrm{C}$, the desorption curve located above adsorption curve.

\subsection{Adsorption\& desorption isotherms modeling}

The experimental points of the equilibrium water content Xeq of the tobacco leaves for three temperatures $\left(40^{\circ} \mathrm{C}, 50^{\circ} \mathrm{C}\right.$ and $60^{\circ} \mathrm{C}$ ) were analyzed by the models of GAB, BET Edit, Peleg, Oswin, Halsey Edit, and Henderson. Tables 4 and 5 show some characteristics of the adsorption isotherms of tobacco leaves.

In order to compare the regression coefficients and the mean relative errors obtained for the different models, it was concluded that the GAB and Peleg models are the most adequate for smoothing the sorption isotherms of the leaves of Nicotiana Tabacum.

In Figures 4, 5 and 6 have indicating the experimental points and the curves obtained by the models used for the leaves of Nicotiana Tabacum L. In the case of adsorption at 40, 50 and $60^{\circ} \mathrm{C}$ in parallel, and Figures 7, 8 and 9 have indicating the experimental points and the curves obtained by the models used in the case of desorption in parallel.

Table 4. Coefficients and static parameters estimation for the adsorption isotherms equations

\begin{tabular}{|c|c|c|c|c|}
\hline \multirow{2}{*}{ Model } & \multirow{2}{*}{ Parameters } & \multicolumn{3}{|c|}{ Temperature } \\
\hline & & $40^{\circ} \mathrm{C}$ & $50^{\circ} \mathrm{C}$ & $60^{\circ} \mathrm{C}$ \\
\hline \multirow{5}{*}{$\mathrm{Gab}$} & $\mathrm{A}$ & $9.91902335 \mathrm{E}-01$ & $9.66006690 \mathrm{E}-01$ & $8.60265606 \mathrm{E}-01$ \\
\hline & B & 7.86051202E-01 & $1.39475339 \mathrm{E}+00$ & $6.98641527 \mathrm{E}-01$ \\
\hline & $\mathrm{C}$ & $1.61164007 \mathrm{E}-01$ & $2.61734890 \mathrm{E}-01$ & $3.45177067 \mathrm{E}-01$ \\
\hline & $\mathrm{s}$ & $2.63680001 \mathrm{E}-02$ & 7.46640507E-02 & 8.02726809E-02 \\
\hline & $r^{2}$ & $9.99848083 \mathrm{E}-01$ & $9.98574906 \mathrm{E}-01$ & $9.91927231 \mathrm{E}-01$ \\
\hline \multirow{5}{*}{ Modified Bet } & A & $-8.00528019 E+03$ & 4.69102198E+04 & $-1.98796502 \mathrm{E}+04$ \\
\hline & B & $2.00135213 \mathrm{E}+02$ & $-9.38201453 \mathrm{E}+02$ & $3.31328741 \mathrm{E}+02$ \\
\hline & $\mathrm{C}$ & $2.07514147 \mathrm{E}+00$ & $1.82499542 \mathrm{E}+05$ & $2.55027131 \mathrm{E}+05$ \\
\hline & $\mathrm{s}$ & $5.68938890 \mathrm{E}-02$ & $2.40028683 \mathrm{E}-01$ & $2.92472189 \mathrm{E}-01$ \\
\hline & $\mathrm{r}^{2}$ & 9.99292539E-01 & 9.85172467E-01 & 8.86867279E-01 \\
\hline \multirow{6}{*}{ Peleg } & A & $1.09662897 \mathrm{E}+00$ & $4.19175022 \mathrm{E}+00$ & $8.90147212 \mathrm{E}-02$ \\
\hline & B & $2.99401645 \mathrm{E}+00$ & $1.27080687 \mathrm{E}+01$ & $-1.45174814 \mathrm{E}-01$ \\
\hline & $\mathrm{C}$ & $5.82391706 \mathrm{E}+00$ & $9.42105793 \mathrm{E}-01$ & $1.71228632 \mathrm{E}+00$ \\
\hline & $\mathrm{D}$ & $2.31257519 \mathrm{E}+01$ & $1.57720912 \mathrm{E}+00$ & $4.81864689 \mathrm{E}+00$ \\
\hline & $\mathrm{s}$ & $5.59135520 \mathrm{E}-03$ & $9.56020577 \mathrm{E}-02$ & $6.13284113 \mathrm{E}-02$ \\
\hline & $\mathrm{r}^{2}$ & 9.99994877E-01 & $9.98247381 \mathrm{E}-01$ & $9.96474006 \mathrm{E}-01$ \\
\hline \multirow{5}{*}{ Oswin } & $\mathrm{A}$ & $-4.39377254 \mathrm{E}+04$ & $-3.99444683 \mathrm{E}+05$ & $-7.51921805 \mathrm{E}+04$ \\
\hline & B & $1.09844725 \mathrm{E}+03$ & 7.98890067E+03 & $1.25320806 \mathrm{E}+03$ \\
\hline & $\mathrm{C}$ & 9.27933170E-01 & 7.20882841E-01 & 5.23927807E-01 \\
\hline & $\mathrm{s}$ & $3.56621988 \mathrm{E}-02$ & 9.60632991E-02 & $1.15731609 \mathrm{E}-01$ \\
\hline & $\mathrm{r}^{2}$ & $9.99722096 \mathrm{E}-01$ & $9.97639855 \mathrm{E}-01$ & $9.83145736 \mathrm{E}-01$ \\
\hline \multirow{5}{*}{$\begin{array}{c}\text { Modified } \\
\text { Halsey }\end{array}$} & A & 4.46220957E+05 & 4.51543190E+04 & $-1.27078038 \mathrm{E}+06$ \\
\hline & B & $-1.11555748 \mathrm{E}+04$ & $-9.03118238 \mathrm{E}+02$ & $2.11796336 \mathrm{E}+04$ \\
\hline & $\mathrm{C}$ & $1.01631513 \mathrm{E}+00$ & $1.28549737 \mathrm{E}+00$ & $1.71813773 \mathrm{E}+00$ \\
\hline & $\mathrm{s}$ & 6.60592867E-02 & $1.13998421 \mathrm{E}-01$ & $1.32990346 \mathrm{E}-01$ \\
\hline & $\mathrm{r}^{2}$ & $9.99046123 \mathrm{E}-01$ & $9.96674697 \mathrm{E}-01$ & $9.77682575 \mathrm{E}-01$ \\
\hline \multirow{5}{*}{ Henderson } & A & $1.46435262 \mathrm{E}+01$ & $-4.28205002 \mathrm{E}-01$ & $5.21534310 \mathrm{E}+00$ \\
\hline & B & $-3.27807854 \mathrm{E}+01$ & $-5.02602898 E+01$ & $-5.76763883 E+01$ \\
\hline & $\mathrm{C}$ & $3.97687000 \mathrm{E}-01$ & $5.48855465 \mathrm{E}-01$ & $8.19185947 \mathrm{E}-01$ \\
\hline & $\mathrm{s}$ & 6.31518940E-02 & $9.88019670 \mathrm{E}-02$ & 8.50608604E-02 \\
\hline & $\mathrm{r}^{2}$ & $9.99128275 \mathrm{E}-01$ & $9.97503195 \mathrm{E}-01$ & $9.90930908 \mathrm{E}-01$ \\
\hline
\end{tabular}

Table 5. Coefficients and statical parameters estimation for the desorption isotherms equations

\begin{tabular}{|c|c|c|c|c|}
\hline \multirow{2}{*}{ Model } & \multirow{2}{*}{ Parameters } & \multicolumn{3}{|c|}{ Temperature } \\
\hline & & $40^{\circ} \mathrm{C}$ & $50^{\circ} \mathrm{C}$ & $60^{\circ} \mathrm{C}$ \\
\hline \multirow{5}{*}{$\mathrm{Gab}$} & $\mathrm{A}$ & $1.01718920 \mathrm{E}+00$ & $9.51641241 \mathrm{E}-01$ & $8.77782896 \mathrm{E}-01$ \\
\hline & B & $9.39243329 \mathrm{E}+00$ & $1.11157826 \mathrm{E}-01$ & $8.45512716 \mathrm{E}+00$ \\
\hline & $\mathrm{C}$ & $1.20641404 \mathrm{E}-01$ & $6.11935102 \mathrm{E}-01$ & $3.05501829 \mathrm{E}-01$ \\
\hline & $\mathrm{s}$ & $1.32192638 \mathrm{E}-01$ & $1.19046901 \mathrm{E}-01$ & $8.34503707 \mathrm{E}-02$ \\
\hline & $r^{2}$ & $9.99036916 \mathrm{E}-01$ & $9.97833806 \mathrm{E}-01$ & 9.94998709E-01 \\
\hline \multirow{5}{*}{$\begin{array}{c}\text { Modified } \\
\text { Bet }\end{array}$} & $\mathrm{A}$ & $-2.85276232 \mathrm{E}+03$ & $3.33060758 \mathrm{E}+04$ & $3.22879412 \mathrm{E}+04$ \\
\hline & B & $7.13259077 \mathrm{E}+01$ & $-6.66118351 E+02$ & $-5.38130853 \mathrm{E}+02$ \\
\hline & $\mathrm{C}$ & $1.60328653 \mathrm{E}-01$ & $3.51702470 \mathrm{E}+00$ & $2.03435196 \mathrm{E}+05$ \\
\hline & $\mathrm{S}$ & $2.49353864 \mathrm{E}-01$ & $1.29291312 \mathrm{E}-01$ & $4.77366627 \mathrm{E}-01$ \\
\hline & $\mathrm{r}^{2}$ & $9.96569019 \mathrm{E}-01$ & $9.97444449 \mathrm{E}-01$ & $8.20675440 \mathrm{E}-01$ \\
\hline \multirow{6}{*}{ Peleg } & $\mathrm{A}$ & $1.17326734 \mathrm{E}+00$ & $5.95121298 \mathrm{E}+00$ & $-1.08900170 \mathrm{E}+02$ \\
\hline & $\mathrm{B}$ & $2.20391553 \mathrm{E}+00$ & $1.26166494 \mathrm{E}+01$ & $2.45266743 \mathrm{E}+00$ \\
\hline & $\mathrm{C}$ & $1.96331830 \mathrm{E}+01$ & $2.36923396 \mathrm{E}-01$ & $1.10839956 \mathrm{E}+02$ \\
\hline & $\mathrm{D}$ & $3.66802839 \mathrm{E}+01$ & $3.54484652 \mathrm{E}-01$ & $2.45266837 \mathrm{E}+00$ \\
\hline & $\mathrm{s}$ & $7.77922196 \mathrm{E}-02$ & $5.99070283 \mathrm{E}-02$ & $2.92370726 \mathrm{E}-01$ \\
\hline & $r^{2}$ & $9.99777735 \mathrm{E}-01$ & $9.99634628 \mathrm{E}-01$ & $9.58306922 \mathrm{E}-01$ \\
\hline
\end{tabular}




\begin{tabular}{ccccc}
\hline & A & $-9.56402222 \mathrm{E}+03$ & $7.94685488 \mathrm{E}+03$ & $-1.47389221 \mathrm{E}+05$ \\
Oswin & B & $2.39103064 \mathrm{E}+02$ & $-1.58932919 \mathrm{E}+02$ & $2.45649542 \mathrm{E}+03$ \\
& C & $1.25314528 \mathrm{E}+00$ & $9.19934249 \mathrm{E}-01$ & $4.26897488 \mathrm{E}-01$ \\
& s & $2.16255267 \mathrm{E}-01$ & $1.25207805 \mathrm{E}-01$ & $1.07647577 \mathrm{E}-01$ \\
& $\mathrm{r}^{2}$ & $9.97420507 \mathrm{E}-01$ & $9.97603518 \mathrm{E}-01$ & $9.91663943 \mathrm{E}-01$ \\
\hline \multirow{5}{*}{ Modified } & $\mathrm{A}$ & $-1.32068406 \mathrm{E}+05$ & $1.24018780 \mathrm{E}+05$ & $6.638892595 \mathrm{E}+03$ \\
Halsey & $\mathrm{B}$ & $3.30166236 \mathrm{E}+03$ & $-2.48041165 \mathrm{E}+03$ & $-1.10678366 \mathrm{E}+02$ \\
& $\mathrm{C}$ & $7.65338378 \mathrm{E}-01$ & $1.02594403 \mathrm{E}+00$ & $2.02489925 \mathrm{E}+00$ \\
& s & $1.95908325 \mathrm{E}-01$ & $1.23351204 \mathrm{E}-01$ & $1.62294889 \mathrm{E}-01$ \\
& $\mathrm{r}^{2}$ & $9.97883560 \mathrm{E}-01$ & $9.97674144 \mathrm{E}-01$ & $9.80949584 \mathrm{E}-01$ \\
\hline \multirow{3}{*}{ Henderson } & A & $2.77051580 \mathrm{E}+01$ & $9.75190910 \mathrm{E}-01$ & $-1.37318276 \mathrm{E}+03$ \\
& B & $-2.61174413 \mathrm{E}+01$ & $-4.94795158 \mathrm{E}+01$ & $-9.22462634 \mathrm{E}+02$ \\
& C & $2.80442838 \mathrm{E}-01$ & $4.01764991 \mathrm{E}-01$ & $1.11706221 \mathrm{E}+00$ \\
& s & $3.09528325 \mathrm{E}-01$ & $1.36925708 \mathrm{E}-01$ & $1.06819686 \mathrm{E}-01$ \\
& $\mathrm{r}^{2}$ & $9.94708342 \mathrm{E}-01$ & $9.97133292 \mathrm{E}-01$ & $9.91792199 \mathrm{E}-01$ \\
\hline
\end{tabular}
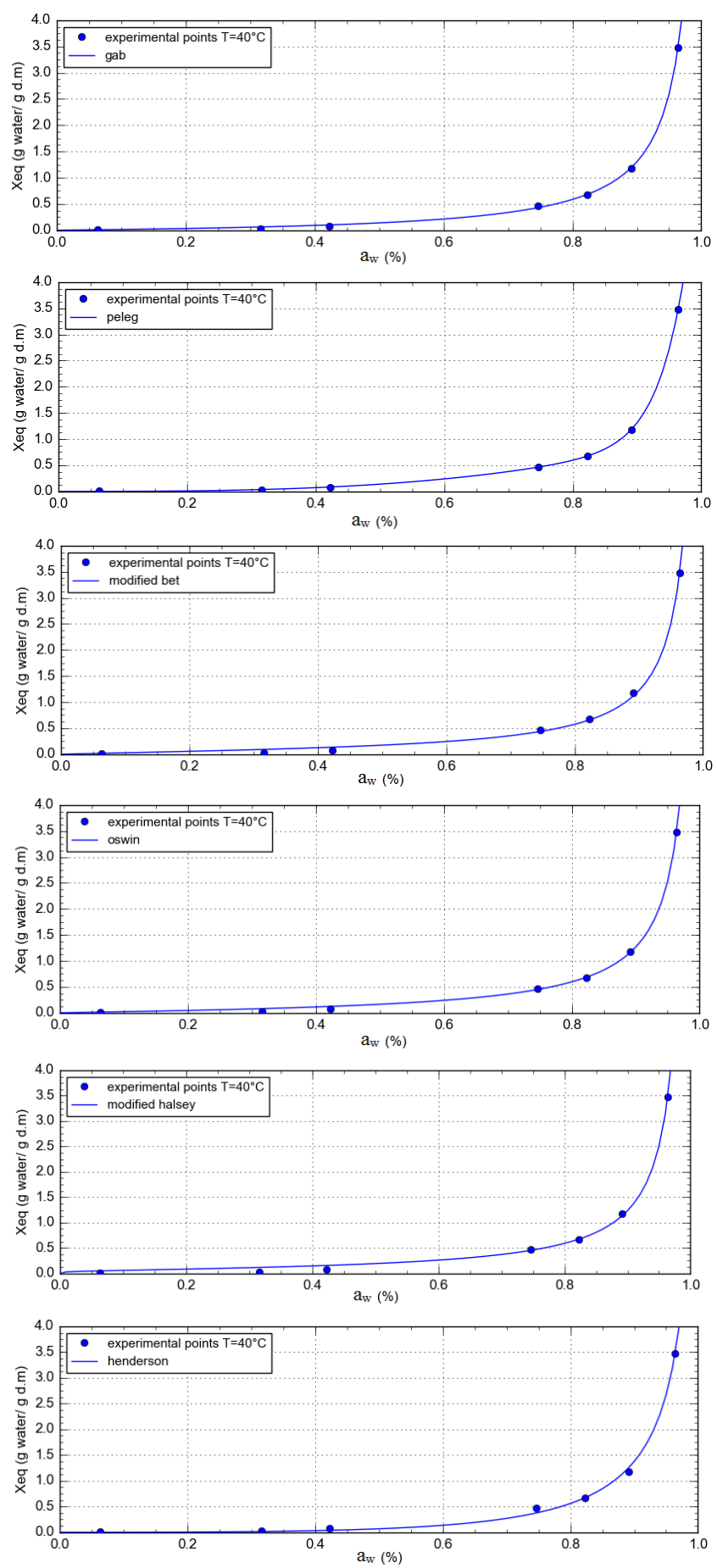

Figure 4. The adsorption isotherms at $\mathrm{T}=40^{\circ} \mathrm{C}$
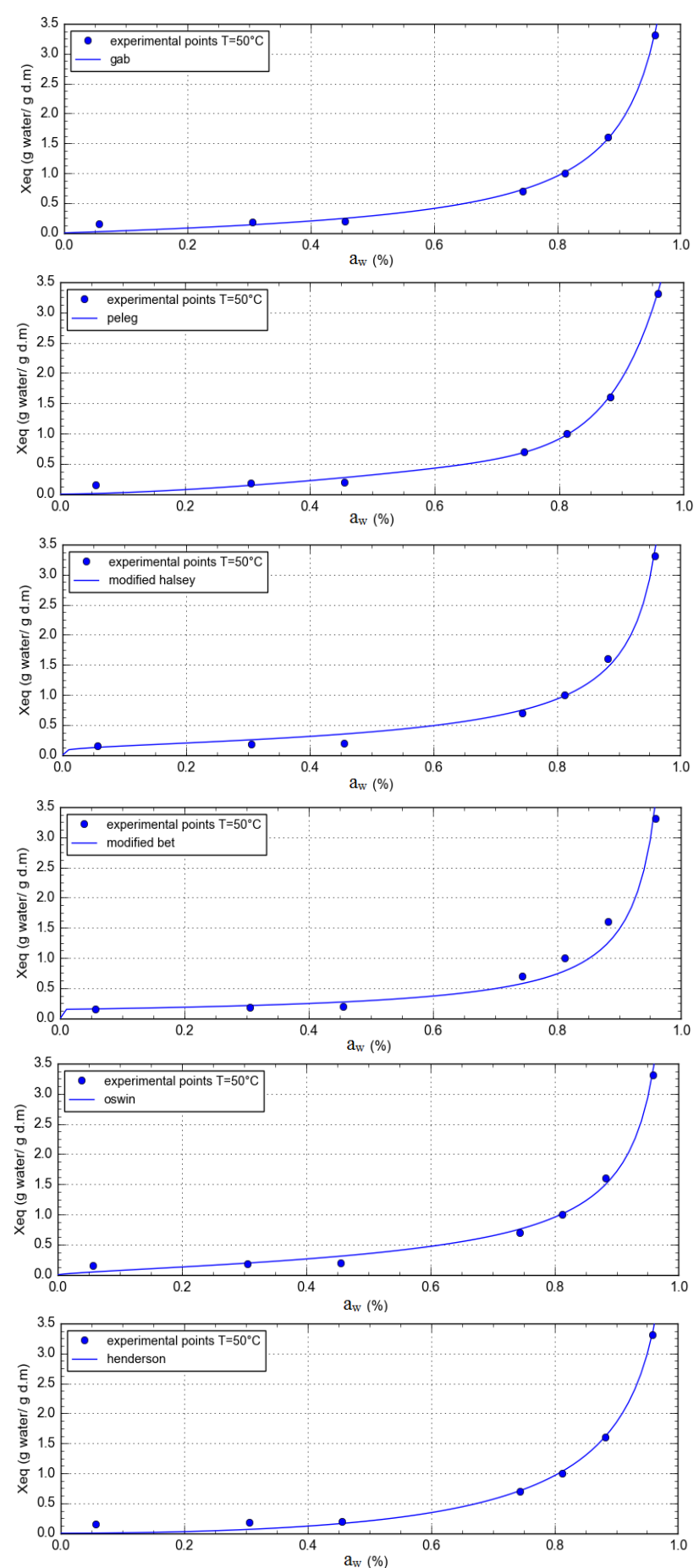

Figure 5. The adsorption isotherms at $\mathrm{T}=50^{\circ} \mathrm{C}$ 

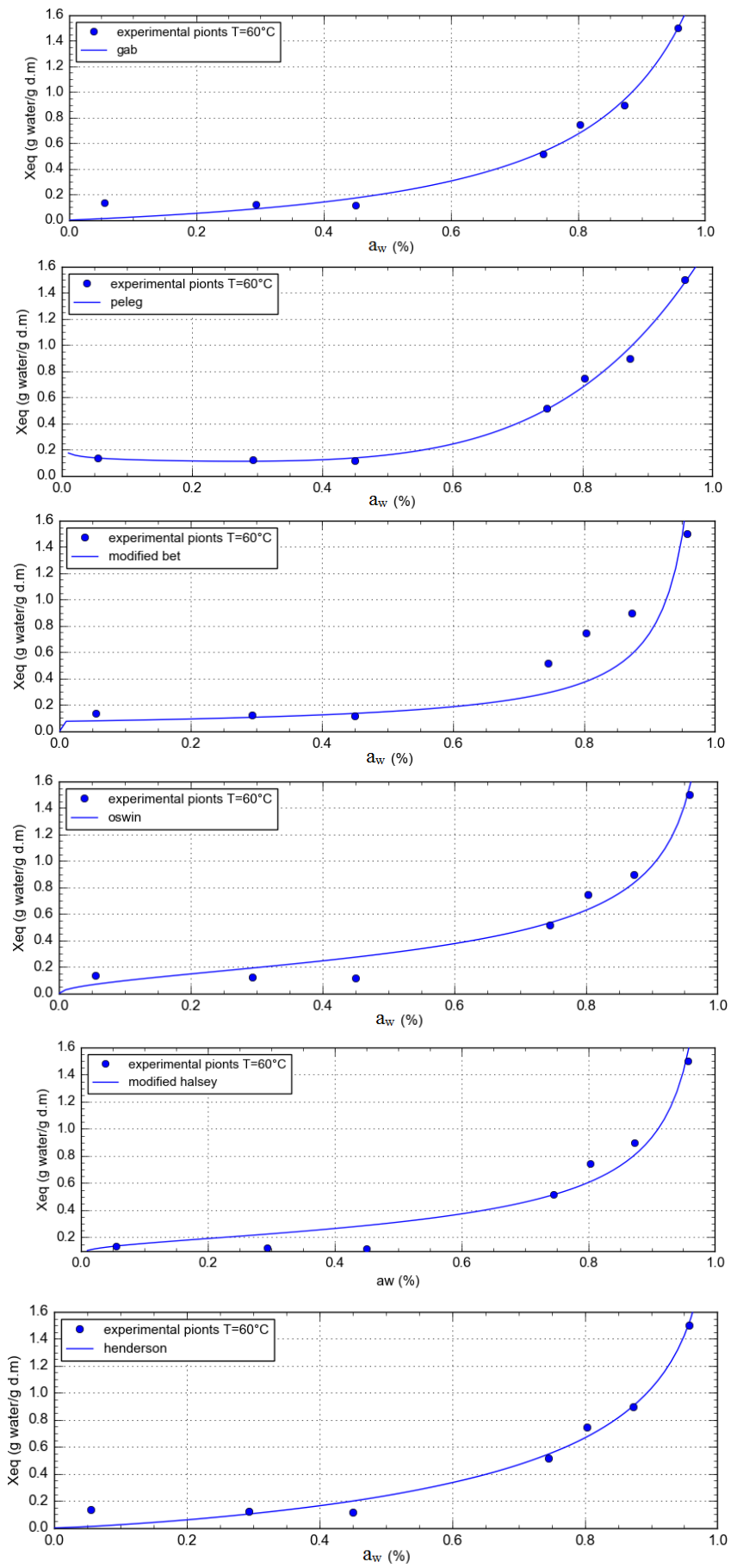

Figure 6. The adsorption isotherms at $\mathrm{T}=60^{\circ} \mathrm{C}$
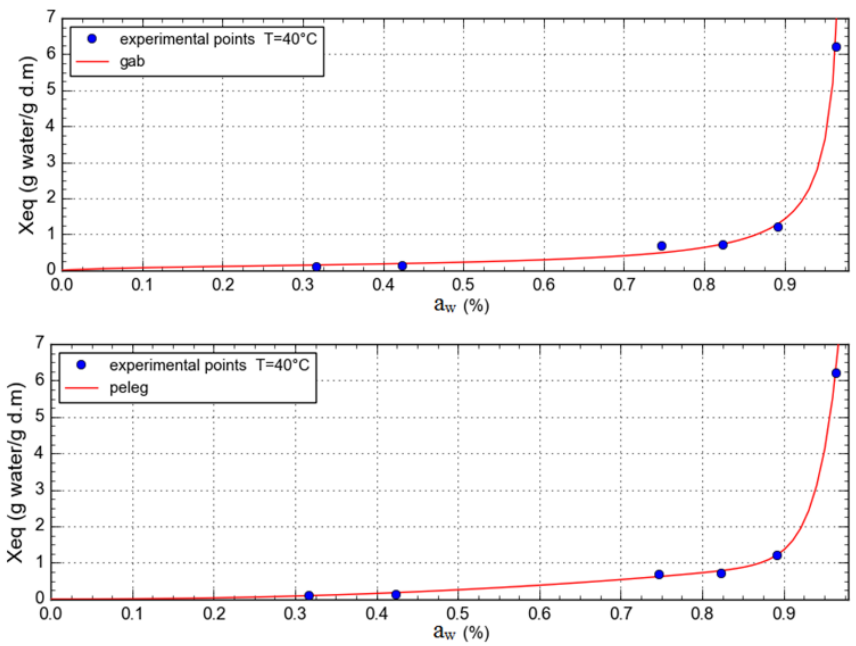
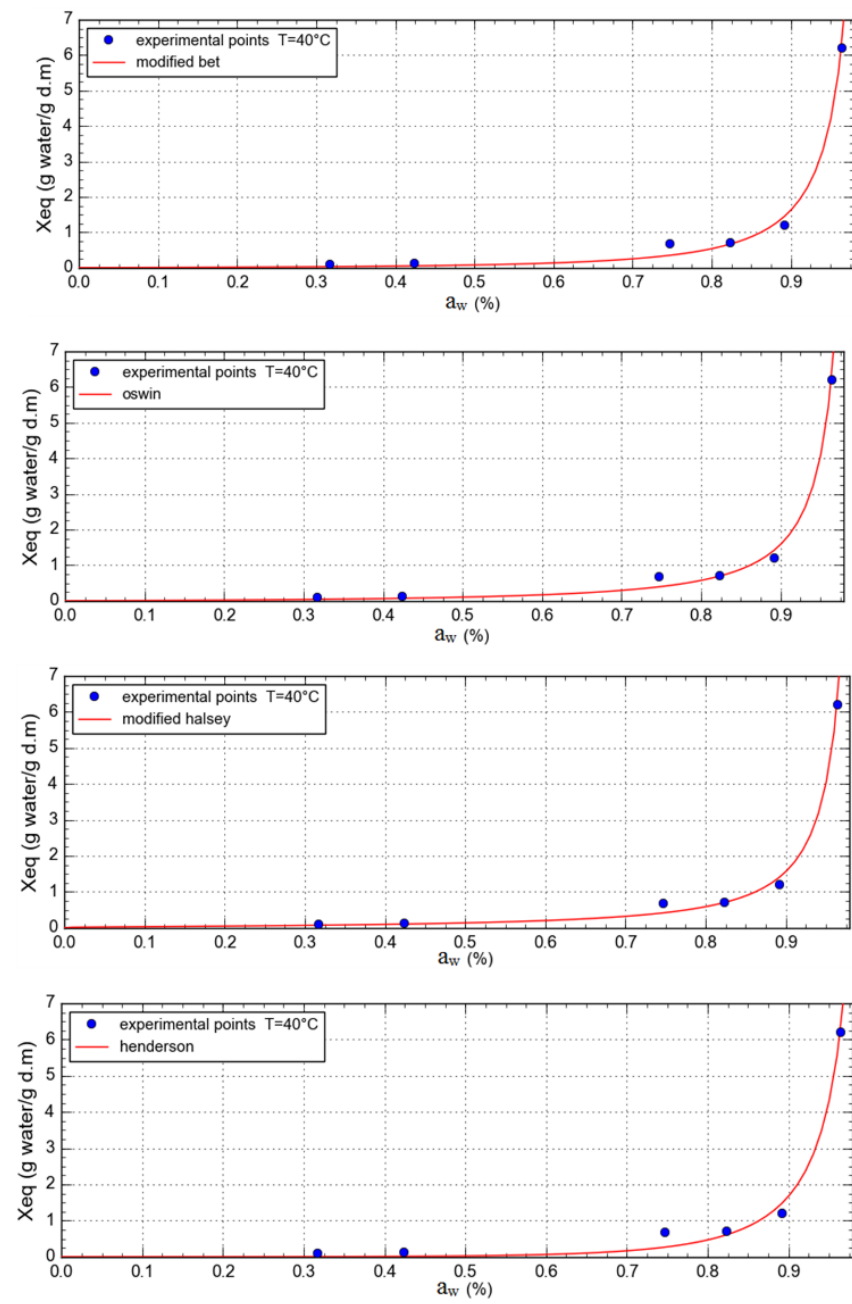

Figure 7. The desorption isotherms at $\mathrm{T}=40^{\circ} \mathrm{C}$
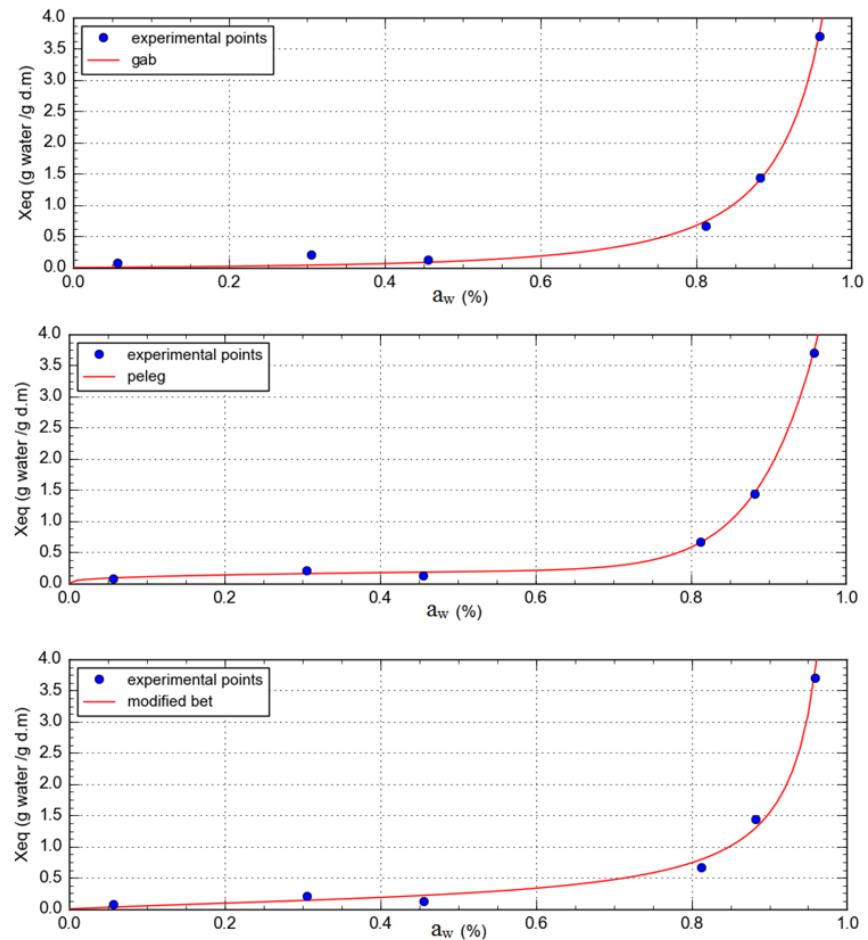

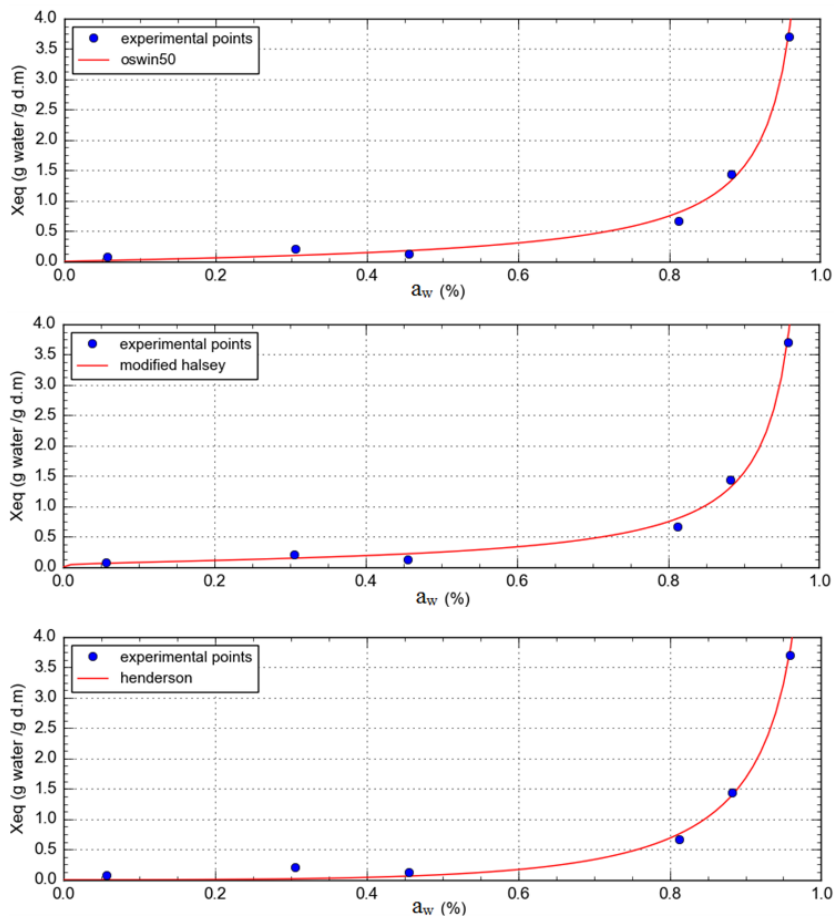

Figure 8. The desorption isotherms at $\mathrm{T}=50^{\circ} \mathrm{C}$
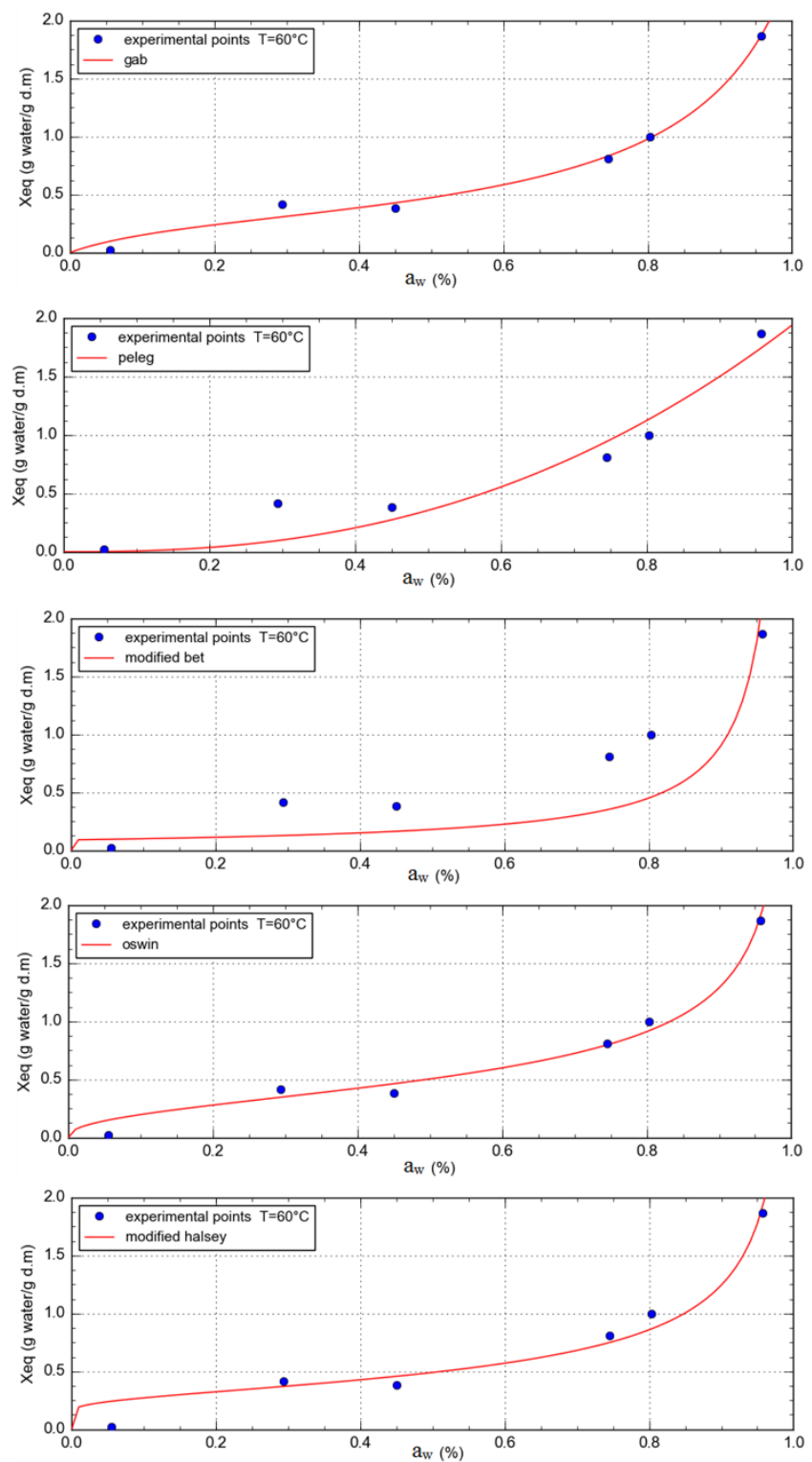

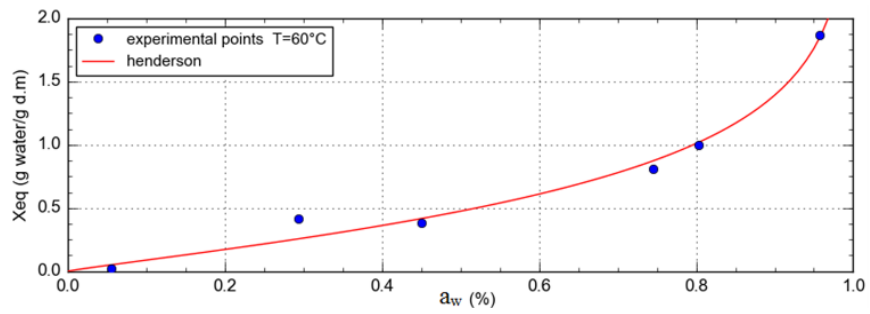

Figure 9. The desorption isotherms at $\mathrm{T}=60^{\circ} \mathrm{C}$

\subsection{Isosteric heat}

The isosteric curves determined for the N.T.L. using aforesaid equations are shown in Figure 10 and 11 . Concerning the increase in the moisture content of product causes a decrease towards zero absolute values of slopes, which is in good agreement with the presented results in the abovementioned references $[11,12]$.

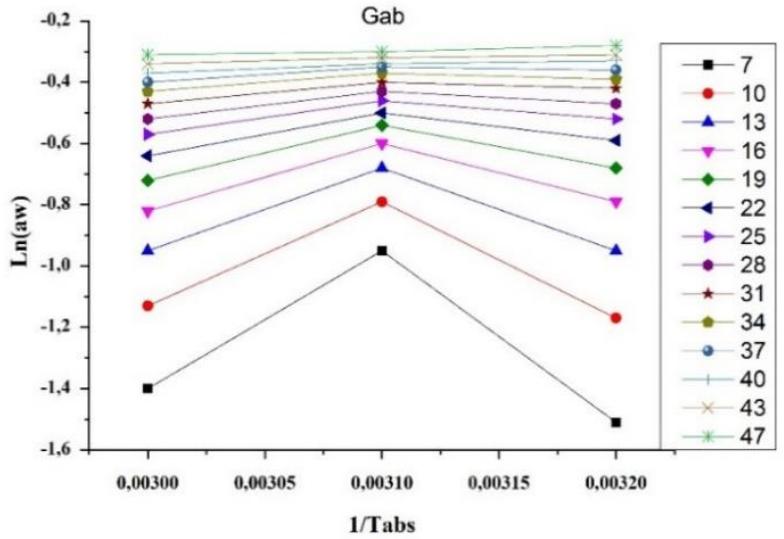

Figure 10. Adsorption isostere curves for GAB model

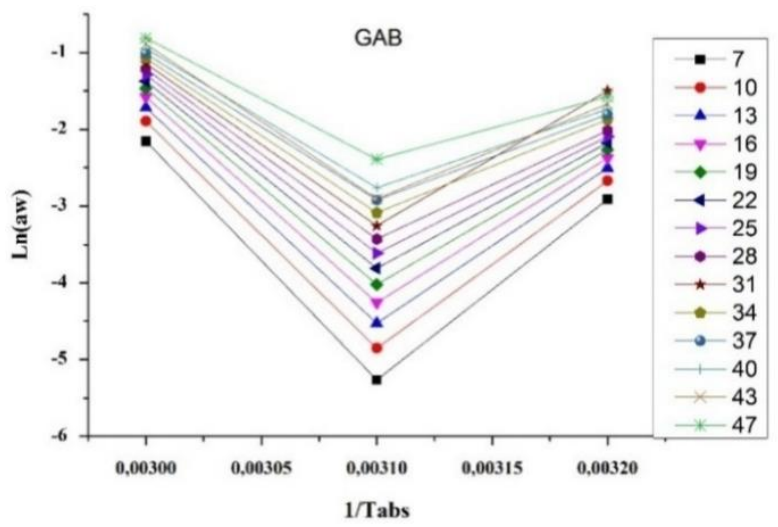

Figure 11. Desorption isostere curves for GAB model

The isosteric net sorption heats obtained for different equilibrium water contents were determined GAB model combined with the Eq (5).

The product desorption variations with the water content are shown in Figure 12 and 13. They show that isosteric heat is more important at low water content, illustrating the strong bond of water to the substrate, and it becomes negligible in the presence of latent heat at high humidity. The following function used to describe the relationship between isosteric sorption heat and equilibrium water content: The desorption and adsorption curves were in good agreement with those 
found in many previous scientific works. Indeed, the water content at equilibrium is inversely proportional to the temperature; this was very clear on the isotherms, when the activity of the water exceeds 0.4 .

Finally, the smoothing of the experimental points allowed us to find experimental equations characterizing the desorption and adsorption at $40^{\circ} \mathrm{C}, 50^{\circ} \mathrm{C}$ and $60^{\circ} \mathrm{C}$.

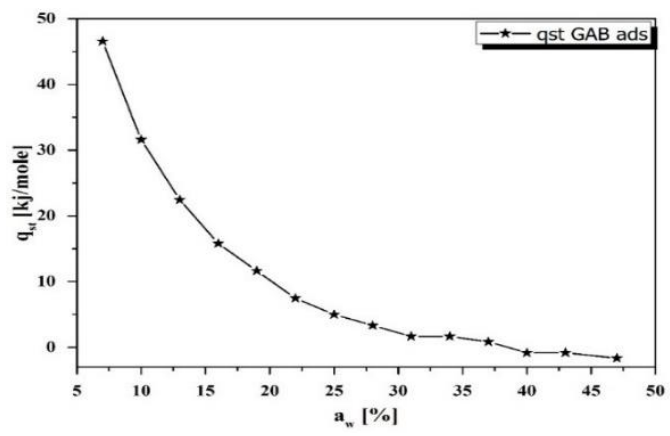

Figure 12. Adsorption isostere heat function as equilibrium water content

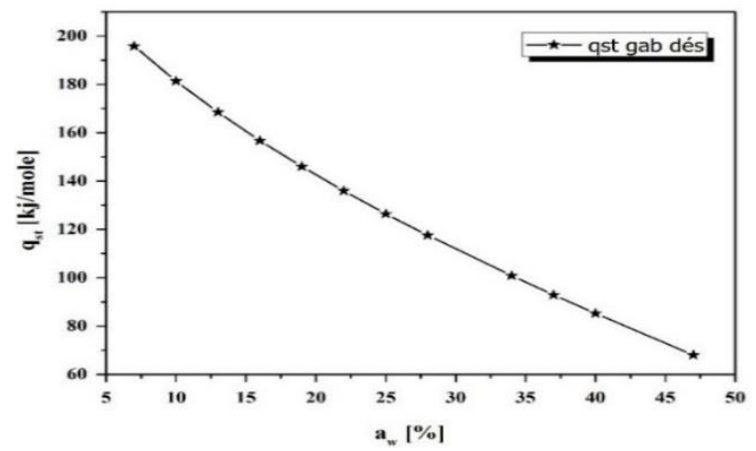

Figure 13. Desorption isosteric heat function as equilibrium water content

\section{CONCLUSION}

This paper is a modest contribution to determine and ongoing discussions about the desorption/adsorption isotherms of N.T.L. plants, on the other hand it is the most important necessary information for agro food drying technology.

The experimental sorption curves have made it possible to determine the maximum temperature thresholds and the final water contents which serve to optimize the drying conditions of the product, the main concern of the paper was to ensure physicochemical and microbiological stability during draying and storage operation.

Both desorption and adsorption isotherms of N.T.L. are determined using the gravimetric method by saturated salt solutions, the experimental results obtained show that the water content of the equilibrium is increased with the decrease in temperature. These results also highlight the hysteresis phenomenon for the same temperature.

The adsorption-desorption isotherms found are type III according to IUAPC and are in good agreement with other studies that have to describe the sorption curves.

Following the smoothing of the experimental results by different used models, it was found that the models of GAB and Peleg allow having the lowest mean relative errors. This allows us to conclude that these models are the most suitable for moisture sorption isotherms on the leaves of N.T.L.

Finally, the net heat of isosteric sorption is calculated, as well as the product life and expiry date can be determined easily.

The experimental sorption curves determination presented a primordial step to performing drying and storage operation, to which the next stage of our research will be involved.

\section{ACKNOWLEDGMENT}

The present work was supported by the solar drying laboratory at the Thermal and Thermodynamics Conversion Division, within the Research Unit at Renewable Energies in the Sahara Medium. Development Centre of Renewable Energies, Adrar, Algeria.

Authors would like to extend his thanks to URERMS for its support in implementing the project.

\section{REFERENCES}

[1] Ren, N., Timko, M.P. (2001). AFLP analysis of genetic polymorphism and evolutionary relationships among cultivated and wild Nicotiana species. Genome, 44(4): 559-571.

[2] Kamen-Kaye, D. (1971). Chimó: An unusual form of tobacco in Venezuela. Bot. Mus. Lealf. Harv. Univ., 23(1): 1-59.

[3] McMurtrey, J.E. (1957). Tobacco. Encyclopaedia Britannica, Incorporated.

[4] Acevedo- Rodríguez, P., Strong, M.T. (2012). Catalogue of seed plants of the West Indies. Smithson. Contrib. to Bot. https://doi.org/10.5479/si.0081024X.98.1

[5] Boussalia, A. (2010). Contribution à l'étude de séchage solaire de produits agricoles locaux. Mémoire présenté en vue l'obtention du Diplôme Magister en Génie Clim. Alger. https://www.thesesalgerie.com/4491346189147551/memoire-demagister/universite-freres-mentouri-constantine1/contribution-a-letude-de-sechage-solaire-de-produitsagricoles-locaux?size=n_10_n.

[6] Daguenet, M. (1985). Les séchoirs solaires: théorie et pratique. Paris: UNESCO. https://www.worldcat.org/title/energiesolaire/oclc/637933041\&referer=brief_results.

[7] Ernest, K.K., Clément, A.D., Verdier, A.N.G., Emmanuel, A.N., Sébastien, N.L. (2015). Isotherme d'adsorption d'eau des feves de cacao (theobroma cacao L.). Marchand. European Scientific Journal, 11(12).

[8] Bennaceur, S., Draoui, B., Touati, B., Saad, A., Bennamoun, L. (2015). Determination of the moisturesorption isotherms and isosteric heat of henna leaves. J Eng Phys Thermophy, 88: 52-62. https://doi.org/10.1007/s10891-015-1167-9

[9] Benhamou, A., Kouhila, M., Zeghmati, B., Benyoucef, B (2010). Modélisation des isothermes de sorption des feuilles de marjolaine. Journal of Renewable Energies, 13(2): 233

[10] Benseddik, A., Azzi, A., Allaf, A.K. (2014). Modélisation des isothermes de désorption de la citrouille en vue de leur séchage solaire. The 3rd International Seminar on New and Renewable Energies 
Unité de Recherche Appliquée en Energies Renouvelables, Ghardaïa - Algérie 13 et 14 Octobre 2014, 173-182.

[11] Lamharrar, A., Kane, C.S.E., Idlimam, A., Akkad, S., Kouhila, M., Mimet, A., Ahachad, M. (2007). Détermination expérimentale des isothermes de sorption et de la chaleur isostérique des feuilles d'absinthe et de menthe pouliot. JITH 2007.

[12] Larbi, A.A., Loumani, A., Mediani, A., Bennaceur, S., Tigani, C. (2019). Experimental measurement of moisture sorption isotherms and isosteric heat of palm hearts (Jomare) harvested in the Algerian Sahara. Instrumentation Mesure Métrologie, 18(3): 297-304. https://doi.org/10.18280/i2m.180310

[13] Mediani, A., Moungar, H., Larbi, A.A., Loumani, A., Chaouch, W.B., Djaber, A., Tigani, C., Benatiallah, A. (2019). The isothermal sorption measurement and the isosteric heats determinations for the South Algerian date varieties. Instrumentation Mesure Métrologie, 18(4): 389-396. https://doi.org/10.18280/i2m.180408

[14] Amira, T., Jihène, L., Fethi, Z. (2015). Isothermes de sorption et propriétés thermodynamique de l'Allium sativum. Journal of the Tunisian Chemical Society, 17: 105-114.

[15] Prasantha, B.D.R., Amunogoda, P. (2013). Moisture adsorption characteristics of solar-dehydrated mango and jackfruit. Food Bioprocess Technol., 6(7): 1720-1728. https://doi.org/10.1007/s11947-012-0832-7

[16] Touati, B., Lips, B., Benyoucef, B., Virgone, J., Jamali, A., Kouhila, M. (2007). Effet de la température sur les isothermes et la chaleur isostérique de sorption des feuilles de menthe (mentha viridis). In: Congres Annuel de la Société Française de la Thermique (SFT'07).

[17] Koko, C.A., Diomande, M., Kan Kouame, B., Assidjo, E.N. (2018). Détermination expérimentale et modélisation des isothermes d'adsorption d'eau des amandes d'Irvingia gabonensis de larégion du HautSassandra (Côte d'Ivoire). IOSR Journal of Environmental Science, Toxicology and Food Technology (IOSR-JESTFT), 12.2(2018): 50-66. https://doi.org/10.9790/2402-1202025066

[18] Taoufik, F., El Hadek, M., Hnini, M.C., Benchanaa, M., El Hammioui, M., Hassani, L.M.I. (2017). Sorption isotherms and isosteric heats of sorption of mint variety (Menthaviridis) leaves and stems: Experimental and mathematical investigations. Eur. Phys. J. Spec. Top., 226(5): 993-1000. https://doi.org/10.1140/epjst/e201660180-1

[19] Kaymak-Ertekin, F., Gedik, A. (2004). Sorption isotherms and isosteric heat of sorption for grapes, apricots, apples and potatoes. LWT-Food Sci. Technol.,
37(4):

$429-438$

https://doi.org/10.1016/j.lwt.2003.10.012

[20] Loumani, A., Larbi, A.A., Mediani, A., Chaouch, W.B., Moungar, H., Tigani, C., Meriama, F., Djaber, A., Bekada, A.M.A. (2020). Experimental measurement of isothermal sorption, microbiological and physicochemical analysis of dried tomatoes cultivated in Adrar, Algeria. International Journal of Design \& Nature and Ecodynamics, 15(5): 721-728. https://doi.org/10.18280/ijdne.150514

[21] Chaouch, W.B., Khellaf, A., Mediani, A., Slimani, M.E.A., Loumani, A., Hamid, A. (2018). Experimental investigation of an active direct and indirect solar dryer with sensible heat storage for camel meat drying in Saharan environment. Sol. Energy, 174: 328-341.

[22] Sing, K.S.W., Everett, D.H., Haul, R.A.W., Moscou, L., Pierotti, R.A., Rouquerol, J., Siemieniewska, T. (1985). Reporting physisorption data for gas/solid systems with special reference to the determination of surface area and porosity. Pure and Applied Chemistry, 57(4): 603-619. https://www.scirp.org/(S(i43dyn45teexjx455qlt3d2q))/r eference/ReferencesPapers.aspx?ReferenceID=201243.

[23] Falade, K.O., Olukini, I., Adegoke, G.O. (2004). Adsorption isotherm and heat of sorption of osmotically pretreated and air-dried pineapple slices. Eur. Food Res. Technol., 218(6): 540-543. https://doi.org/10.1007/s00217-004-0900-y

[24] Nasfi, N., Bagane, M. (2017). Détermination experimentale et modelisation des isothermes de sorption du LaurusNobilis. L Du Sud Tunisien. IOSR Journal of Environmental Science, Toxicology and Food Technology, 11(3): 52-56. https://doi.org/10.9790/24021103015256

[25] Jannot, Y. (2008). Isothermes de sorption: Modeles et détermination. Links. https://www.doc-developpementdurable.org/file/Energie/Solairethermique/cours/cours\%20isotherme\%20de\%20sorption .pdf.

\section{NOMENCLATURE}

$\begin{array}{ll}\text { aw } & \text { water activity (dimensionless) } \\ \mathrm{r}^{2} & \text { correlation coefficient }[-] \\ \mathrm{T} & \text { temperature }\left[{ }^{\circ} \mathrm{C}\right] \\ \mathrm{Xeq} & \text { equilibrium moisture content }[\mathrm{kg} / \mathrm{kg}] \\ \mathrm{Hr} & \text { relative humidity } \% \\ \mathrm{~A}, \mathrm{C}, \mathrm{k}, \mathrm{B}, \mathrm{q}, \mathrm{S} & \text { model coefficients } \\ \mathrm{Q}_{0} & \text { net isosteric heat of desorption }[\mathrm{J} / \mathrm{mol}] \\ \text { N.T.L. } & \text { Nicotiana Tabacum Lives }\end{array}$

